\title{
Financial Analysis Of Bank Al Bilad
}

Carl B. McGowan, Jr., Norfolk State University, USA

Andrew R. Stambaugh, Norfolk State University, USA

Zunaidah Sulong, Universiti Sultan Zainal Abidin, Malaysia

\begin{abstract}
This paper presents a model for the financial analysis of a bank based on the DuPont system of financial analysis. The DuPont system of financial analysis is derived from an analysis of return on equity that consists of three parts: 1) operating efficiency as measured by profit margin, 2) asset use efficiency as measured by total asset turnover, and 3) financial leverage as measured by the equity multiplier. The analysis covers the period from mid 2005 to 2009. The DuPont system of analysis assesses the performance of the Arabian institution since its establishment in the Spring of 2005.
\end{abstract}

Keywords: DuPont analysis; bank analysis; Islamic banking; ROE

\section{INTRODUCTION}

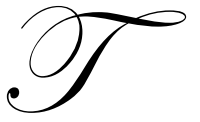

he effective financial management of corporations and financial institutions is achieved in a similar fashion. Managers of both parties accomplish their chief purpose through maximizing the value of the firm. The value of a firm is derived from an examination of the decisions of the firm's managing body. The risk and return relationship exhibited in managerial decisions is reflected in the total market capitalization of the firm, computed as stock value multiplied by the number of outstanding shares. Financial managers impact this equilibrium through their responsibility to make judgment calls in two regards - investment decisions, or those concerning assets use, operating industry selection, and the degree of operating leverage, and financing decisions, or those concerning the capital structure of the firm and the degree of financial leverage. Essentially, investment decisions answer the question of where to allocate funds, whereas financial decisions answer the question of whether to employ debt or equity financing to fund a project. The third type of managerial decision encountered in financial management in known as a dividend decision. This decision generally refers to one that either involves allocation of funds, but is not an investment decision, or affects the financing of a firm, but is not a financing decision.

Future cash flows of a firm are a result of managerial decisions. Based on these decisions, one is able to estimate the expected value of future cash flows, as well as the corresponding deviation. Furthermore, from the cash flow estimates, we can determine the value of a firm. The value of the firm is calculated as the expected cash flow divided by required rate of return. By using the same model as corporate financial managers, one can assess the value of a bank, adjusting for the distinctions between product and service-oriented establishments.

\section{BANK AL BILAD}

Bank Al Bilad is a Saudi joint stock company established under Royal Decree on November 4, 2004. The bank received commercial registration on April 19, 2005. This paper analyzes all financial statements available subsequent to the day of commercial registration. Operating twenty-one branches and sixty exchange and remittance centers in the Kingdom of Saudi Arabia, Bank Al Bilad provides banking and investment services to both private and commercial parties in the region. With a head office in Riyadh, the bank currently has a corporate capital of three billion Saudi Riyals. The bank's operates within the standards of Sharia law, or the sacred law of Islam. Sharia law prohibits riba, one of the Seven Heinous Sins listed in the Qu'ran, otherwise known as usury (Muhammad, 2010). Bank Al Bilad operates in accordance with this prohibition through use of Murabaha, Bei Ajel, and Musharaka investment arrangements. 


\section{A FINANCIAL ANALYSIS MODEL FOR FINANCIAL INSTITUTIONS}

As presented in Saunders (2000) and appied in Collier, et al., (2010), the DuPont system of financial analysis is one based on return on equity. According to the formula, the three elements of return on equity are net profit margin, total asset turnover, and the equity multiplier. Net profit margin alludes to a company's profitability in regards to their ability to control costs. A more profitable company with more control over costs would exhibit a profit margin higher than competitors. Total Asset Turnover is a measure of a company's efficiency in using assets to generate sales. The higher that this ratio is, the better. The equity multiplier is a measure of leverage. A higher equity multiplier ratio shows that an institution is relying more heavily on debt financing to obtain funds. As implied, these ratios can be useful tools in comparing a company to its competitors or overall industry. Return on equity, as computed from the other three ratios, is a measure of profitability, suggesting how much profit is being generated with investors' money. Through use of these ratios, we are able to construct pro forma financial statements.

Return on equity is calculated by multiplying return on assets by the equity multiplier. Return on assets is calculated by multiplying net profit margin by total asset turnover:

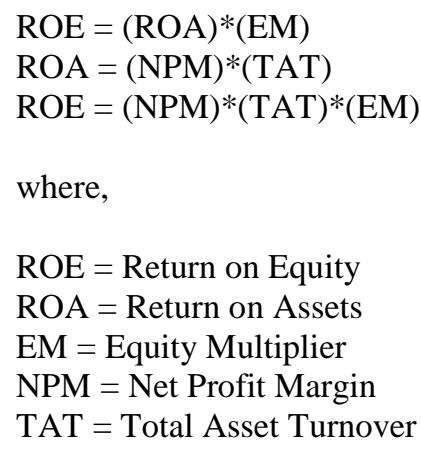

Net profit margin is calculated as net profit (or loss) divided by total revenue. Total asset turnover is calculated as total revenue divided by total assets. The equity multiplier is calculated as total assets divided by total stockholders' equity:

$\mathrm{NPM}=(\mathrm{NI}) /(\mathrm{TR})$

$\mathrm{TAT}=(\mathrm{TR}) /(\mathrm{TA})$

$\mathrm{EM}=(\mathrm{TA}) /(\mathrm{TSE})$

where,

NPM $=$ Net Profit Margin

$\mathrm{NI}=$ Net Income

$\mathrm{TR}=$ Total Revenue

$\mathrm{TAT}=$ Total Asset Turnover

$\mathrm{TA}=$ Total Assets

$\mathrm{EM}=$ Equity Multiplier

TSE $=$ Total Stockholders' Equity

\section{FINANCIAL ANALYSIS OF BANK AL BILAD - BALANCE SHEET ITEMS}

Table 1 contains financial statements, balance sheet, and income statement for Bank Al Bidah for 2005 to 2009. Bank Al Bilad has four major asset categories: cash and balances with Saudi Arabian Monetary Agency (SAMA), dues from banks and other financial institutions, investments and financing, and fixed and other assets. Cash and balances with SAMA were relatively stable throughout the time frame nearing SAR 1.2 billion for 2005, 2008, and 2009 while reaching its lowest point of SAR 702 million in 2006 and peaking at almost SAR 2.06 billion 
in 2007. The average figure, calculated using data from the full financial statement periods from 2006 to 2009 , was SAR 1.2 billion. Due from banks and other financial institutions grew exponentially during the first three years to its peak of SAR 6.07 billion in 2007. It would thereafter decline to SAR 2.83 billion in 2009. The average figure was SAR 3.2 billion. Investments have steadily increased from 2005's low of SAR 5.21 billion to SAR 12.55 billion in 2009, more than doubling. The average investment figure was near SAR 10 billion. Fixed assets would peak in 2007 at SAR 964 million following its lowest figure of SAR 400 million in 2005. The average was SAR 801 million.

Bank Al Bilad has three major liability accounts: customer deposits, other liabilities, and shareholders' funds. Customer deposits increased to SAR 12.7 billion in 2007 but fell to short of SAR 11 billion the following year. It has since recovered, reaching SAR 13.7 billion in 2009. The average of customer deposits was SAR 11.3 billion. Other liabilities more than doubled every for the first four years, reaching a peak of SAR 1.87 billion in 2008. In 2009, it would fall to slightly more than one-third of the peak value at SAR 688 million, creating a four year average of SAR 949 million. Shareholders' funds increased by SAR 100 million, more or less, each year between the date of registration and 2008, reaching SAR 3.2 billion. Since falling to SAR 3 billion, shareholders' funds averaged over the four year period at SAR 3 billion.

\section{FINANCIAL ANALYSIS OF BANK AL BILAD - INCOME STATEMENT ITEMS}

As briefly discussed before, Bank Al Bilad operates in accordance with Islamic religious beliefs. As such, it is forbidden to engage in exchanges in which interest gains are involved. However, to remain competitive with the remainder of the business globe, financial institutions in regions of Islamic religious practice employ the use of alternative investment structures known as Murabaha and Musharaka. In murabaha, a sale price that includes a margin of profit for the seller is agreed upon between two parties and the loan is either paid back in installments or paid in full. It is structured much like a rent-to-own arrangement and is an acceptable way of securing a credit sale under Sharia law. Musharaka is an acceptable method of commercial lending. Instead of issuing loans at specified rates of interest, as is custom in western societies, Musharaka involves the sharing of profits or losses according to predetermined ratio. Bei Ajel, the third form of investment listed on the income statement, is similar to Murabaha, defined by Bank Al Bilad as an agreement between the bank and its customers whereby the bank sells to a customer a commodity or an asset, which the bank has purchased and acquired, based on a promise received from the customer to buy at a selling price that comprises the cost plus an agreed profit margin.

Bank Al Bilad receives income from two major channels: income from investments and financing and income from fees, commissions, and other non-interest income. Income from investments increased steadily from the date of registration to 2008 reaching SAR 578 million. It would reduce to SAR 538 million the following year. The average income from investments for the four year period is SAR 504 million. Other income would fluctuate from SAR 54 million in 2005 to SAR 359 million in 2009. The average income from other activities amounts to SAR 299 million.

Bank Al Bilad's expenses fall into five major categories: salaries and employee related benefits, rent and premises related expenses, depreciation and amortization, provision and impairment charges, and other miscellaneous expenses. Employee related expenses steadily rose from SAR 104 million in 2005 to SAR 391 in 2009. The four year average is SAR 340 million. Premises related expenses also rose from SAR 23 million in 2005 to SAR 106 million in 2009, averaging SAR 87 million. Depreciation and amortization costs exhibited a similar pattern rising from SAR 8.7 million in 2005 to SAR 139 million in 2009 for an average of SAR 107 million. Provision and Impairment expenses were sporadic, amounting to SAR 7 million in 2006, SAR 84 million in 2008, and SAR 363 in 2009. The average expense in this category was SAR 113 million.

\section{DISCUSSION OF FINANCIAL RATIOS}

Table 2 contains percent of assets, percent of sales ratios, and the ratios used to compute the DuPont analysis for Bank Al Bilad. As a percent of total assets, cash and balances with SAMA averages $8.27 \%$ with a high of $18.34 \%$ in 2005 and a low of $6.23 \%$ in 2006. Due from other banks and financial institutions averages 19.53\% with a high of $36.51 \%$ in 2007 and a low of $1.1 \%$ in 2006. Investment and financing average $66.94 \%$ with a high of 
$87 \%$ in 2006 and a low of $45.32 \%$ in 2007. Fixed and other assets exhibit the least variability with an average of $5.26 \%$, a high of $5.8 \%$ in 2007 , and a low of $4.24 \%$ in 2009.

As a percent of total assets, cash and balances with SAMA averages $8.27 \%$ with a high of $18.34 \%$ in 2005 and a low of $6.23 \%$ in 2006. Dues from other banks and financial institutions averages $19.53 \%$ with a high of $36.51 \%$ in 2007 and a low of $1.1 \%$ in 2006. Investment and financing average $66.94 \%$ with a high of $87 \%$ in 2006 and a low of $45.32 \%$ in 2007. Fixed and other assets exhibit the least variability with an average of $5.26 \%$, a high of $5.8 \%$ in 2007 , and a low of $4.24 \%$ in 2009 .

As a percentage of total liabilities, customer deposits averaged $73.27 \%$, other liabilities averaged $6.05 \%$, and shareholders' funds averaged $20.68 \%$. Customer deposits were at their highest percentage in 2009 at $78.8 \%$ and lowest percentage in 2005 at $55.89 \%$. Other liabilities were at their highest percentage in 2008 at $11.64 \%$ and lowest percentage in 2005 at $2.72 \%$. Shareholders' funds were at their highest percentage in 2005 at $41.39 \%$ and lowest percentage in 2009 at $17.24 \%$.

As a percentage of total revenue, employee related expenses were at their highest in 2005 at $63.96 \%$ and their lowest in 2006 at $37.57 \%$ with a four year average of $42.18 \%$. Premises related expenses were at their highest in 2005 at $14.83 \%$ and their lowest in 2008 at $10.49 \%$ with a four year average of $10.89 \%$. Depreciation and amortization was at its highest in 2009 at $15.32 \%$ and is lowest in 2005 at $5.34 \%$ with a four year average of $13.21 \%$. Provision and impairment charges were at their highest in 2009 at $40.03 \%$ and their lowest in $2005 \& 2007$ at $0 \%$ with a four year average of $12.70 \%$. Other miscellaneous expenses were at their highest in 2005 at $75.88 \%$ and their lowest in 2008 at $9.65 \%$ with a four year average of $15.15 \%$.

\section{DUPONT ANALYSIS OF BANK AL BILAD}

Net profit margin averages $5.86 \%$ with a range from $-60 \%$ in 2005 to $27.2 \%$ in 2006 . Figure 1 shows net profit margin for Bank Al Bilad. Total asset turnover averages 0.053 times with a range from 0.023 times in 2005 to 0.058 times in 2006. Figure 2 shows total asset turnover for Bank Al Bilad. The equity multiplier averages 4.97 with a range from 2.4 times to 5.79 times in 2009. Figure 3 shows the equity multiplier for Bank Al Bilad. Return on equity for Bank Al Bilad exhibits a four-year average of 96 basis points, or $0.96 \%$, but ranges from $-3.38 \%$ in 2005 to $5.81 \%$ in 2006. Figure 4 shows return on equity for Bank Al Bilad.

Return on equity volatility stems from significant variability in the component parts of return on equity: net profit margin, total asset turnover, and the equity multiplier, Collier, et al., (2010). Institutions in the financial industry tend to exercise a higher level of financial leverage and, consequently, exhibit higher equity multipliers. Therefore, by adjusting for the equity multiplier we are able to determine how much of the return on equity was derived from profit margins and sales. In $2005,1.4 \%$ of the negative return on equity was derived from sales and profit margin where the bank's leverage contributed $1.98 \%$. In $2006,1.58 \%$ of the return on equity was derived from sales and profit margin where leverage contributed $4.31 \%$. In $2007,0.44 \%$ of the return on equity was derived from sales and profit margin where leverage contributed $1.90 \%$. In $2008,0.78 \%$ of the return on equity was derived from sales and profit margin where leverage contributed $3.11 \%$. In $2005,1.43 \%$ of the negative return on equity was derived from sales and profit margin where leverage contributed $6.85 \%$. Likely, the most recent financial ratios were influenced considerably by the economic strains of the western hemisphere that echoed in the global market.

\section{SUMMARY AND CONCLUSIONS}

This paper presents a model for the financial analysis of a bank based on the DuPont system of financial analysis presented in Saunders (2000) and used in Collier, et al., (2010). Return on equity of the bank is disaggregated into three parts: 1) net profit margin, 2) total asset turnover, and 3) the equity multiplier due to leverage. The DuPont system of financial analysis tracks the performance of Bank Al Bilad. From analysis of the ratios, we are able to deduce that Bank $\mathrm{Al}$ Bilad has relied on debt to a higher degree each year to exhibit its return on equity figures, indicating a lower percentage of return on equity being derived from sales activities, or income from banking operations, and profit margin. This is a not an abnormal symptom for a bank that has endured relatively few seasons. However, it should be noted that indications to the contrary would be a good sign, if not 
ideal. It is anticipated, given the conditions of the region's developing capital market and its proximity to the lucrative oil industry and profiting governments that Bank Al Bilad will recover from the inconveniences evidenced in its most recent financial statements.

\section{AUTHOR INFORMATION}

Carl B. McGowan, Jr., PhD, CFA is a Professor of Finance at Norfolk State University, has a BA in International Relations (Syracuse), an MBA in Finance (Eastern Michigan), and a PhD in Business Administration (Finance) from Michigan State. From 2003 to 2004, he held the RHB Bank Distinguished Chair in Finance at the Universiti Kebangsaan Malaysia and has taught in Cost Rica, Malaysia, Moscow, Saudi Arabia, and The UAE. Professor McGowan has published in numerous journals including Applied Financial Economics, Decision Science, Financial Practice and Education, The Financial Review, International Business and Economics Research Journal, The International Review of Financial Analysis, The Journal of Applied Business Research, The Journal of Business Case Studies, The Journal of Diversity Management, The Journal of Real Estate Research, Managerial Finance, Managing Global Transitions, The Southwestern Economic Review, and Urban Studies.

Andrew R. Stambaugh is an Honors student at Norfolk State University and majoring in management information systems and finance. He has been a member of the Spanish Club, the Society for the Advancement of Management, the Finance and Banking Association, the Honors College at NSU, the NSU School of Business Honors Council, the Alpha Kappa Mu Honor Society, the Golden Key International Honour Society, and the Beta Gamma Sigma Honor Society and has made the Dean's list every semester he has been enrolled at NSU.

Zunaidah Sulong is a lecturer in the Department of Finance and Banking, Faculty of Business Management and Accountancy, Universiti Sultan Zainal Abidin (UniSZA). She is currently the Deputy Dean for research and postgraduate studies. Prior to joining UniSZA in 2009, she served Universiti Putra Malaysia (UPM) for 5 years. During her tenure at UPM, she won the Best Paper Award (finance category) at the Faculty Seminar 2007. She also won 1 Silver and 2 Bronzes awards in 2008 and 1 Silver award in 2007 at the UPM Research Exhibition. Dr. Zunaidah holds a Doctorate in Business Administration and a Master of Business Administration from Universiti Kebangsaan Malaysia. In addition, she has also obtained a Bachelor of Business Administration (Honours) degree in Finance from Universiti Utara Malaysia. Her current research interests focus on issues related to corporate finance, governance, auditing as well as Islamic finance, banking, and accounting. Her articles have been published in several national and international refereed journals, such as International Journal of Business Governance \& Ethics, International Business Research, Journal of Modern Accounting and Auditing, International Business \& Economics Research Journal, Southwest Review of International Business Research, Capital Markets Review, Malaysian Accounting Review, Sinergi - Kajian Bisnis \& Manajemen and Jurnal Siasat Bisnis. She has also actively participates in various local and international conferences.

\section{REFERENCES}

1. Collier, Henry W., Carl B. McGowan, Jr., and Junaina Muhammad. "Evaluating the Impact of a Rapidly Changing Economic Environment on Bank Financial Performance Using the Dupont System of Financial Analysis," Asia Pacific Journal of Finance and Banking Research, Volume 4, Number 4, 2010, pp. 25-35.

2. Muhammad, Junaina and Carl B. McGowan, Jr. "The Theoretical Impact of the Listing of SyariahApproved Stocks on the Stock Price and Trading Volume," International Business \& Economics Research Journal, Volume 9, Number 3, March 2010, pp. 11-19

3. Bank Al Bilad Financial Statements, 2005-2009

4. Saunders, Anthony. Management of Financial Institutions, Third Edition, McGraw Hill, 2000. 
Table 1: Arabian Bank Alibad Financial Statements (SAR'000)

\begin{tabular}{|c|c|c|c|c|c|c|}
\hline Income Statement - Income & 2005 & 2006 & 2007 & 2008 & 2009 & Average \\
\hline $\begin{array}{l}\text { Net Income from Investing and } \\
\text { Financing Assets }\end{array}$ & 109251 & 358953 & 534441 & 578265 & 548114 & $504,943.25$ \\
\hline $\begin{array}{l}\text { Fee and Commission, Exchange, } \\
\text { and other Non-interest Income }\end{array}$ & 54237 & 295946 & 244127 & 296314 & 359666 & $299,013.25$ \\
\hline Net Revenue & 163488 & 654899 & 778568 & 874579 & 907780 & $803,956.50$ \\
\hline Income Statement - Expenses & & & & & & Average \\
\hline $\begin{array}{l}\text { Salaries and Employee Related } \\
\text { Benefits }\end{array}$ & 104561 & 246013 & 356692 & 369456 & 391341 & $340,875.50$ \\
\hline Rent and Premises Related Expenses & 24240 & 70809 & 82146 & 91782 & 106403 & $87,785.00$ \\
\hline Depreciation and Amortization & 8727 & 69202 & 103764 & 119058 & 139111 & $107,783.75$ \\
\hline Other Miscellaneous Expenses & 124052 & 83737 & 163507 & 84411 & 155967 & $121,905.50$ \\
\hline Provision \& Impairment Charges & 0 & 7019 & 0 & 84803 & 363347 & $113,792.25$ \\
\hline Total Expenses & 261580 & 476780 & 706109 & 749510 & 1156169 & $772,142.00$ \\
\hline Net Loss/Income & -98092 & 178119 & 72459 & 125069 & -248389 & $31,814.50$ \\
\hline Balance Sheet - Assets & 2005 & 2006 & 2007 & 2008 & 2009 & Average \\
\hline $\begin{array}{l}\text { Cash and Balances with Saudi } \\
\text { Arabian Monetary Agency (SAMA) }\end{array}$ & 1284560 & 702726 & 2058151 & 1125142 & 1297241 & $1,295,815.00$ \\
\hline $\begin{array}{l}\text { Due from Banks and other Financial } \\
\text { Institutions }\end{array}$ & 109158 & 124274 & 6074145 & 3894328 & 2826483 & $3,229,807.50$ \\
\hline Investments \& Financing & 5211605 & 9824825 & 7539210 & 10158613 & 12549754 & $10,018,100.50$ \\
\hline Fixed and Other Assets & 400101 & 629539 & 964332 & 873706 & 737714 & $801,322.75$ \\
\hline Total Assets & 7005424 & 11281364 & 16635838 & 16051789 & 17411192 & $15,345,045.75$ \\
\hline \multicolumn{7}{|l|}{ Balance Sheet - Liabilities } \\
\hline Customer Deposits & 3915450 & 7858059 & 12689285 & 10971045 & 13720627 & $11,309,754.00$ \\
\hline Other Liabilities & 190651 & 398960 & 842446 & 1867904 & 688383 & $949,423.25$ \\
\hline Shareholders' Funds & 2899323 & 3024345 & 3104107 & 3212840 & 3002182 & $3,085,868.50$ \\
\hline $\begin{array}{l}\text { Total Liabilities and } \\
\text { Shareholders' Equity }\end{array}$ & 7005424 & 11281364 & 16635838 & 16051789 & 17411192 & $15,345,045.75$ \\
\hline
\end{tabular}

Figure 1: Net Profit Margin

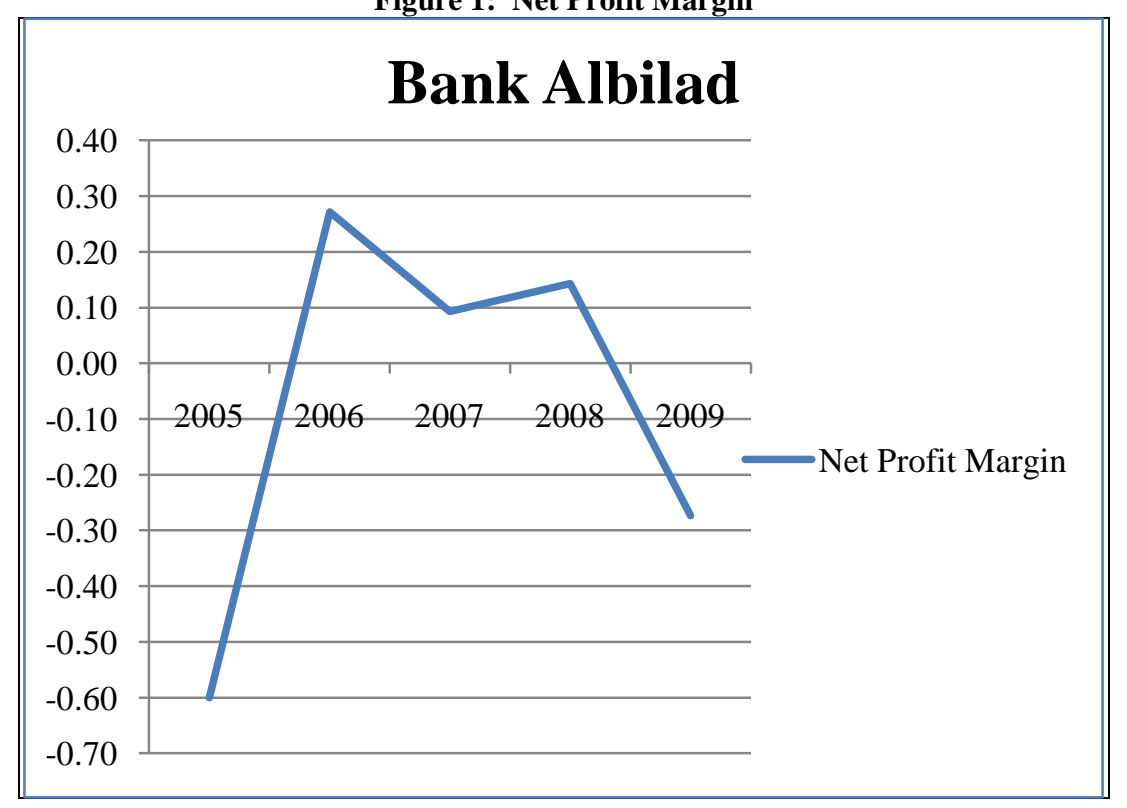


Table 2: Arabian Bank Alibad Ratio Computations (SAR'000)

\begin{tabular}{|c|c|c|c|c|c|c|}
\hline Balance Sheet - Assets & 2005 & 2006 & 2007 & 2008 & 2009 & Average \\
\hline $\begin{array}{l}\text { Cash and Balances with Saudi Arabian } \\
\text { Monetary Agency (SAMA) }\end{array}$ & $18.34 \%$ & $6.23 \%$ & $12.37 \%$ & $7.01 \%$ & $7.45 \%$ & $8.27 \%$ \\
\hline $\begin{array}{l}\text { Due from Banks and other Financial } \\
\text { Institutions }\end{array}$ & $1.56 \%$ & $1.10 \%$ & $36.51 \%$ & $24.26 \%$ & $16.23 \%$ & $19.53 \%$ \\
\hline Investments \& Financing & $74.39 \%$ & $87.09 \%$ & $45.32 \%$ & $63.29 \%$ & $72.08 \%$ & $66.94 \%$ \\
\hline Fixed and Other Assets & $5.71 \%$ & $5.58 \%$ & $5.80 \%$ & $5.44 \%$ & $4.24 \%$ & $5.26 \%$ \\
\hline Total Assets & $100.00 \%$ & $100.00 \%$ & $100.00 \%$ & $100.00 \%$ & $100.00 \%$ & $100.00 \%$ \\
\hline Balance Sheet - Liabilities & 2005 & 2006 & 2007 & 2008 & 2009 & Average \\
\hline Customer Deposits & $55.89 \%$ & $69.66 \%$ & $76.28 \%$ & $68.35 \%$ & $78.80 \%$ & $73.27 \%$ \\
\hline Other Liabilities & $2.72 \%$ & $3.54 \%$ & $5.06 \%$ & $11.64 \%$ & $3.95 \%$ & $6.05 \%$ \\
\hline Shareholders' Funds & $41.39 \%$ & $26.81 \%$ & $18.66 \%$ & $20.02 \%$ & $17.24 \%$ & $20.68 \%$ \\
\hline $\begin{array}{l}\text { Total Liabilities and Shareholders' } \\
\text { Equity }\end{array}$ & $100.00 \%$ & $100.00 \%$ & $100.00 \%$ & $100.00 \%$ & $100.00 \%$ & $100.00 \%$ \\
\hline Income Statement Items & 2005 & 2006 & 2007 & 2008 & 2009 & Average \\
\hline Salaries and Employee Related Benefits & $63.96 \%$ & $37.57 \%$ & $45.81 \%$ & $42.24 \%$ & $43.11 \%$ & $42.18 \%$ \\
\hline Rent and Premises Related Expenses & $14.83 \%$ & $10.81 \%$ & $10.55 \%$ & $10.49 \%$ & $11.72 \%$ & $10.89 \%$ \\
\hline Depreciation and Amortization & $5.34 \%$ & $10.57 \%$ & $13.33 \%$ & $13.61 \%$ & $15.32 \%$ & $13.21 \%$ \\
\hline Other Miscellaneous Expenses & $75.88 \%$ & $12.79 \%$ & $21.00 \%$ & $9.65 \%$ & $17.18 \%$ & $15.15 \%$ \\
\hline Provisions \& Impairment Charges & $0.00 \%$ & $1.07 \%$ & $0.00 \%$ & $9.70 \%$ & $40.03 \%$ & $12.70 \%$ \\
\hline Profit Margin & $-60.00 \%$ & $27.20 \%$ & $9.31 \%$ & $14.30 \%$ & $-27.36 \%$ & $5.86 \%$ \\
\hline Total - Income Statement & $100.00 \%$ & $100.00 \%$ & $100.00 \%$ & $100.00 \%$ & $100.00 \%$ & $100.00 \%$ \\
\hline DuPont Ratios & 2005 & 2006 & 2007 & 2008 & 2009 & Average \\
\hline Profit Margin (PM) & -0.6000 & 0.2720 & 0.0931 & 0.1430 & -0.2736 & 0.0586 \\
\hline Asset Utilization (TAT) & 0.0233 & 0.0581 & 0.0468 & 0.0545 & 0.0521 & 0.0529 \\
\hline Equity Multiplier (EM) & 2.4162 & 3.7302 & 5.3593 & 4.9961 & 5.7995 & 4.9713 \\
\hline Return on Equity (ROE) & -0.0338 & 0.0589 & 0.0233 & 0.0389 & -0.0827 & 0.0096 \\
\hline ROE (\%) & $-3.38 \%$ & $5.89 \%$ & $2.33 \%$ & $3.89 \%$ & $-8.27 \%$ & $0.96 \%$ \\
\hline ROE NON-EM (\%) & $-1.40 \%$ & $1.58 \%$ & $0.44 \%$ & $0.78 \%$ & $-1.43 \%$ & $0.34 \%$ \\
\hline ROE from EM & $-1.98 \%$ & $4.31 \%$ & $1.90 \%$ & $3.11 \%$ & $-6.85 \%$ & $0.62 \%$ \\
\hline
\end{tabular}

Figure 2: Total Asset Turnover

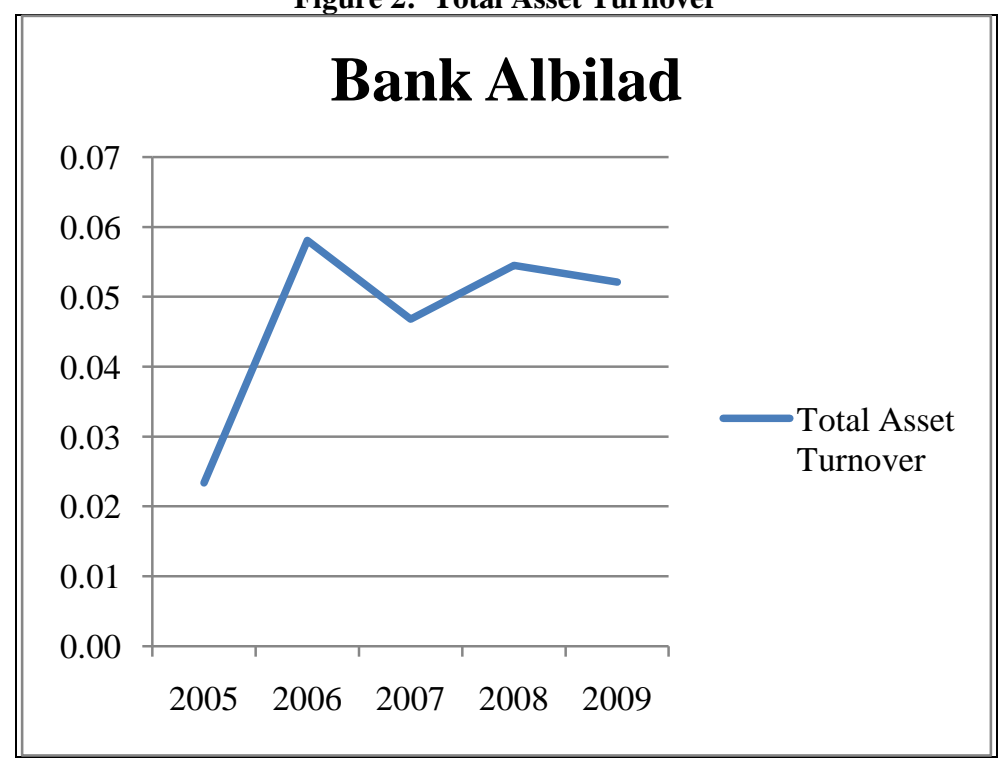


Figure 3: Equity Multiplier

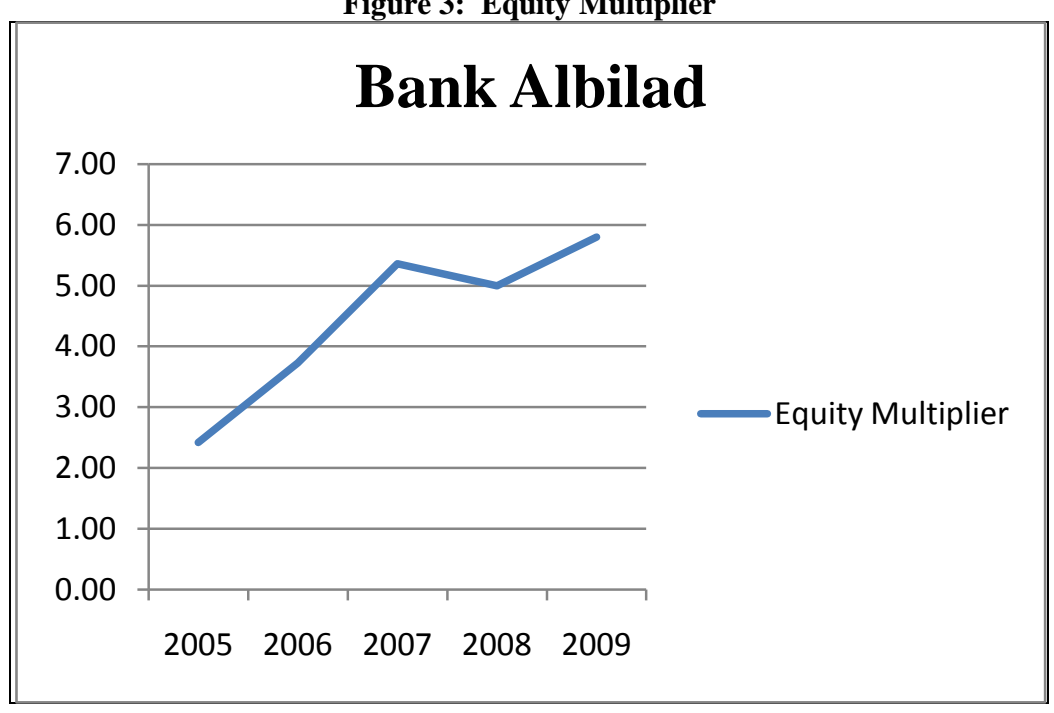

Figure 4: Return on Equity

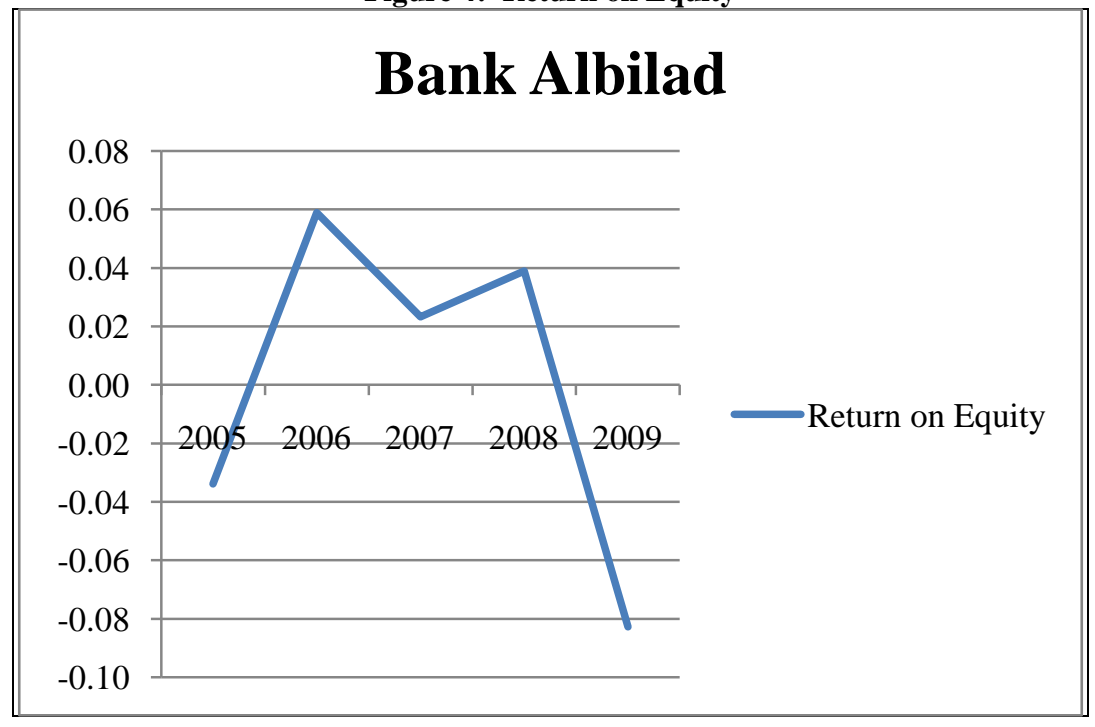

